\title{
Adoption of soil test recommendations by the farmers
}

\section{J. R. SALI, S. U. MOKHALE, D. G. PADEKAR AND H. K. RAJPUT}

MEMBERS OF RESEARCH FORUM:

Corresponding author :

S. U. MOKHALE, Department of

Extension Education, Shri Shivaji

Agriculture College, AMRAVATI (M.S.) INDIA

Co-authors :

J.R. SALI, D.G. PADEKAR AND

H.K. RAJPUT, Department of Extension Education, Shri Shivaji Agriculture College, AMRAVATI (M.S.) INDIA

\section{Summary} respondents had major constraints. AJSS/11.2/358-360.
Received : 22.06.2016; Accepted : 30.11.2016

The present study on adoption of soil test recommendations by the farmers was conducted in the year 2015-16 in Chandur Bazar and Bhatkuli tehsils of Amravati district. For this study 100 respondents were selected with the help of random sampling method. The data were collected with the help of structured interview schedule. Collected data were carefully examined, classified quantified and tabulated. Frequencies, mean, standard deviation, correlation of coefficient analysis were employed for interpreting the results. Results obtained after analysis have been summarized as below. The findings of the present investigation indicate that near half 47.00 per cent of the respondents were in old age group and 38.00 per cent respondents were educated upto high school level. More than one third of respondents 35.00 per cent had small land holding upto 1.01-2.00 ha. 33.00 per cent respondents had annual income in between Rs. 50,000 to 1,00,000. Over half 52.00 per cent of the respondents having medium level of extension contact. The 71.00 per cent respondents having no source for irrigation availability. 82.00 per cent respondents were taking seasonal crops. The 59.00 per cent of respondents were having low level of motivation. 41.00 per cent of respondents were having medium level of innovativeness towards adoption of soil test recommendations. 52.00 per cent of the respondents were having medium level of availability of fertilizers. The majority of respondents 48.00 per cent had high understanding about soil test recommendations, only 34.00 and 18.00 per cent of the respondents having medium and low understanding about soil testing, respectively. The most of the respondents 76.00 per cent were having low level of adoption about soil test recommendations, only 19.00 per cent respondents were having medium adoption level and 5.00 per cent respondents were having high level of adoption of soil test recommendations. In the study it was found that education, annual income, extension contact, cropping pattern, motivation, innovativeness, availability of fertilizers and understanding of soil test recommendations were positive and significantly related with adoption at 0.01 level of significance and irrigation availability was positivey and significantly related with adoption at 0.05 level of significance. Age and land holding were found to be non-significantly related with adoption. Lack of knowledge about nutrient management, soil test report not clear to the

Key words : Adoption, Soil test, Fertilizer, Nutrient, Understanding, Farmers

How to cite this article : Sali, J.R., Mokhale, S.U., Padekar, D.G. and Rajput, H.K. (2016). Adoption of soil test recommendations by the farmers. Asian J. Soil Sci., 11 (2) : 358-360 : DOI : 10.15740/HAS/ 